\title{
A First Assessment of the Conservation of the Mummified Human Remains in the Museo Egizio in Turin in the Framework of the "Mummy Conservation Project"
}

\author{
Marco Samadelli, Giulia Gregori, Frank Maixner, Marco Rossani, Paolo Del Vesco, \\ Matilde Borla, Alice Paladin, Christina Wurst, Katja Sterflinger-Gleixner, \\ Christian Voitl, Marta Cibin, Gregory S. Thomas, Bruno Frohlich, \\ Randall C. Thompson, Albert R. Zink
}

The Museo Egizio in Turin holds a unique collection of 116 mummified or skeletal human bodies or body parts. This collection is currently under study by the "Mummy Conservation Project", a collaborative venture of the Museo Egizio, the Institute for Mummy Studies of Eurac Research, the Soprintendenza Archeologia del Piemonte, and the Horus Group, whose aim is to improve mummy conservation techniques. In the context of this project, an assessment of the state of preservation of the mummified human remains was carried out by monitoring basic physical parameters (temperature, relative humidity and water activity) and by performing a fungal survey. The latter revealed the presence on the mummified material of fungal spores and mycelia that could possibly pose a biodegradative threat. However, all the current physical parameters show that the mummies are stored under optimal environmental conditions, which will suppress any microbial up-growth.

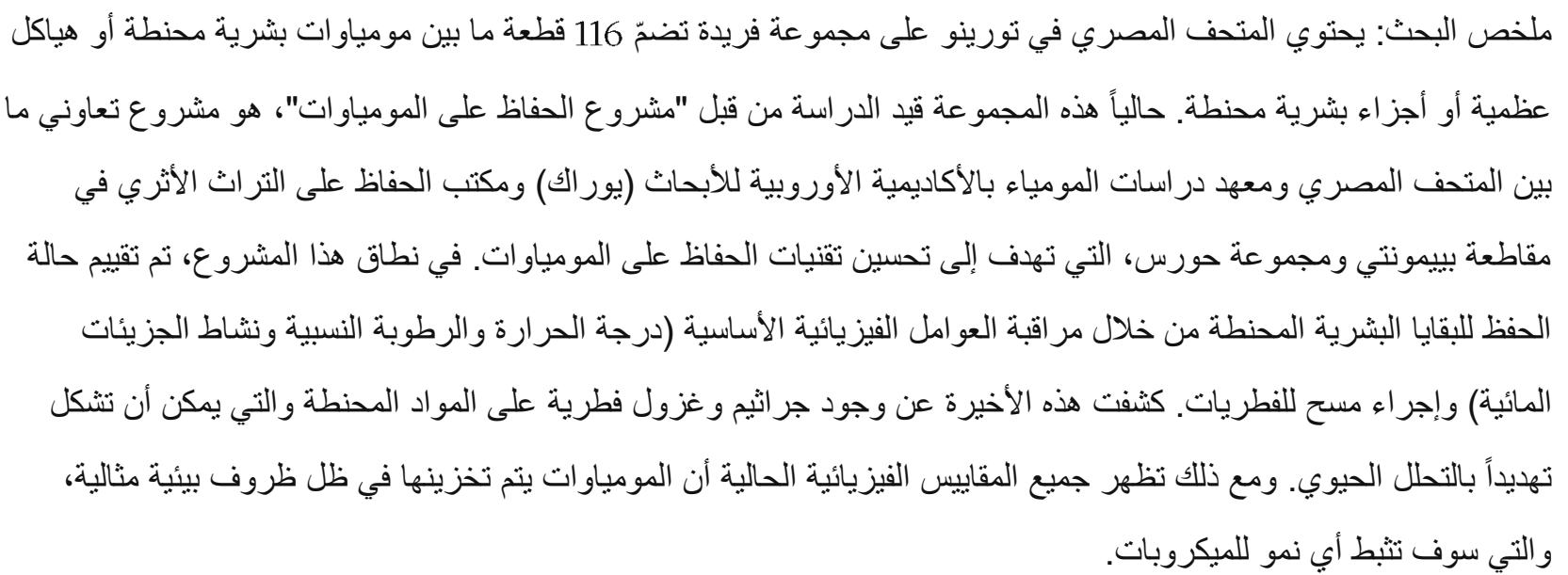

\section{Introduction}

The first set of Egyptian mummies arrived in $\mathrm{Tu}-$ rin following the scientific/commercial expedition undertaken by the traveler and naturalist, Vitaliano Donati, a professor of botany at the University of Turin, at the behest of King Charles Emmanuel III of Savoy between 1759 and 1762. In Egypt, Donati collected some 1,689 scientific samples and objects, ${ }^{1}$ including eighteen animal mummies. A second group of mummies, many probably coming from the ancient Egyptian capital city of Thebes (modern-day Luxor in southern Egypt), was collected by Bernardino Drovetti, Consul General of France to Egypt, and was bought, for the Turin collection, 
by the Savoy king Charles Felix in $1824 .^{2}$ In 1888 , when the two-volume catalogue of the Museo Egizio was completed by Ariodante Fabretti (1816-1894), Francesco Rossi (1827-1912) and Rodolfo Vittorio Lanzone (1834-1907), it included a total of twelve complete human mummies, nine heads - two of which were associated with a hand - two hands with rings, four pseudo-mummies, and seventy-eight animal mummies. The human mummies entered the collection inside wooden anthropoid coffins, and the inscriptions that grace these coffins specify the names and professions of the deceased they were meant for, supposedly the same people whose mummified bodies were contained in the coffins. ${ }^{3}$ Finally, thanks to Ernesto Schiaparelli, director of the Museo Egizio between 1894 and 1928, the number of mummies in the collection was further increased. A buying trip to Egypt, done by Schiaparelli in 1900/1901, led to the purchase of more than 1,500 items, including two naturally mummified adult bodies and the mummy of a small child dating to about 3500 BCE. But it is especially since the foundation of the Italian Archaeological Mission to Egypt in 1903 that a large number of human remains was discovered at various sites along the Nile, during many excavation seasons directed by Egyptologists Ernesto Schiaparelli and, later on, Giulio Farina, who were assisted, since 1914, by anthropologist Giovanni Marro. ${ }^{4}$ A total of 116 mummified or skeletal human bodies and body parts are recorded today in the Museum database as coming from these fieldwork campaigns, but 20 more mummies, 650 complete skeletons, and 144 skulls, presently held in the Turin Museum of Anthropology and Ethnography, ${ }^{5}$ most likely also derive from the same excavations.

Given the increasing attention among researchers to the mummified human remains held in the Museo Egizio in Turin, in 2016 the "Mummy Conservation Project" was set up, with the aim of incorporating the data and knowledge acquired so far on these human remains in order to develop a protocol for proper museum conservation and display.

The goals of the "Mummy Conservation Project" illustrated in this paper were the following:

- Taking thermo-hygrometric measurements in the galleries, the inside of display cases, in the mum- my storage room, and in the room where the research operations were carried out.

- Measuring the water activity (aw) of the mummies.

- Fungal spore sampling of the air in the galleries, inside a display case, in the mummy storage room, and in the room where the research operations were carried out.

- Fungal survey of the mummified material.

\section{Research aim}

In view of the Museo Egizio and Eurac Research's common interest in developing know-how to help preserve all the Museo Egizio's mummies - both those on display and those in storage - special emphasis was placed on testing water activity (aw), a parameter that affects the rate of biochemical decay in organic tissues. This important parameter is significantly affected by temperature and relative humidity in the conservation environment. In parallel to the assessment of this physical parameter, a first microbial survey was performed.

To identify the presence of possible superficial growing fungi, samples of both textiles and skin were taken using non-invasive contact plates.

To obtain further knowledge of the environmental conditions the mummies are presently experiencing, the researchers also took samples of spores present in the air inside the storage room where the mummies were kept, in a display case in the permanent galleries, and in the room where the research operations were carried out.

The aim of this work is to expand on research on the conservation organic objects of historical and artistic interest by assessing both biological and physical-chemical conservation requirements.

\section{Material and methods}

\subsection{Thermo-hygrometric measurement of the exhibition areas, inside a display case, in the mummy storage room, and in the room where the research operations were carried out}

Thanks to historical data relative to the thermo-hygrometric conditions of the museum's exhibition spaces and the storage space where the mummies were kept (prior to the inauguration of the new galleries in 2015), it was possible to identify the sea- 


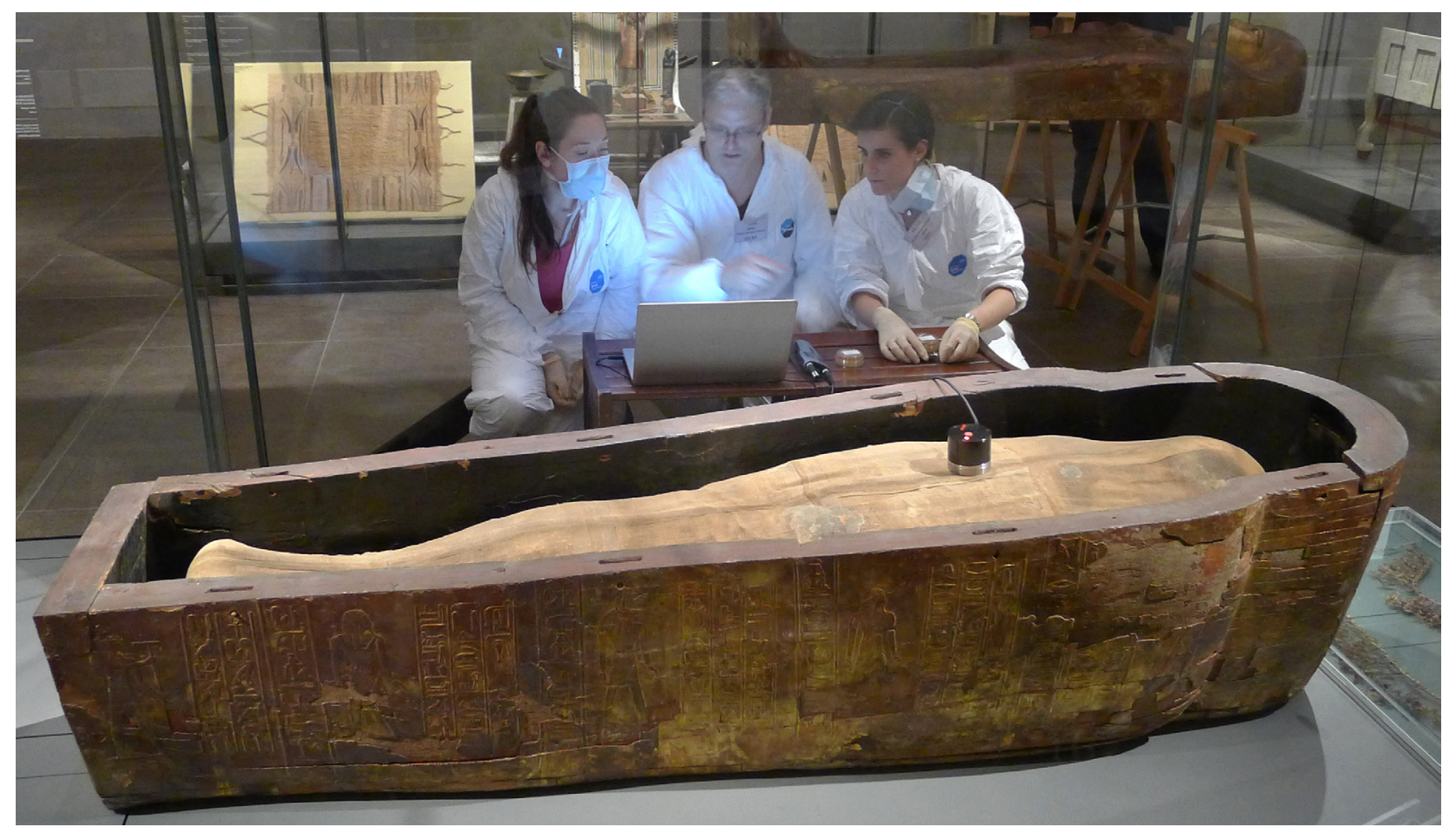

Fig. 1: A phase of a non-invasive water activity (aw) test carried out on the mummy of Kha (Suppl. 8431). Picture by Eurac Research, Institute for Mummy Studies.

sonal trend these relics were subjected to.

With the exception of the room where the Tomb of Kha and Merit was display - where a wall-mounted air conditioner and a portable humidifier were installed - all the rest of the museum and storage lacked an air conditioning system. Climate monitoring took place in "sample" mode over different periods and in different areas of the museum with the aid of data loggers (HumiStick). The recorded temperature ranged between $21^{\circ} \mathrm{C}$ and $30^{\circ} \mathrm{C}$, and the recorded relative humidity between $30 \%$ and $66 \%$. In 2015, a new air conditioning system was installed, serving all the exhibition halls, the Foundation's offices, and the storage spaces. It is powered by an underground thermo-cooling plant using geothermal energy.

To date, the museum's different exhibition areas have depended on auxiliary machines whose temperature and relative humidity values can be individually and independently set.

\subsection{Measuring water activity (aw) of the mummies}

As regards this specific phase of the project, a total of 106 organic samples were analysed, both of a vegetal nature (bandage linen) and of human origin (fragments of bone, skin, muscles, connective tissue, hair, Fig. 1).

To measure the water activity (aw) value, the Rotronic instrument, model HygroPalm HP-23-AW-A, was used. Prior to measuring the samples, the HC2$\mathrm{AW}$ and the relative Rotronic HC2-SH measurement probe were calibrated as needed.

Immediately after sampling the mummified organic tissues, the water activity of the samples was examined. The samples were then placed inside special sample holders, previously sterilised. The Rotronic HW4 software version 3.8.0 was used to validate the measurements obtained. Once the PC was connected to the analyser, it was possible, through this application, to set the necessary operating settings in order to obtain the measurement (Fig. 2).

Simultaneously with the water activity (aw) acquisition phase, the temperature and relative humidity values of the environment were obtained. The time required to acquire each sample is approximately 5 minutes. At the end of each acquisition, a validation certificate was produced in form of a PDF file.

\subsection{Sampling and cultivation of fungi}

Non-invasive sampling using contact agar plates (DG18 and $2 \%$ MEA, Merck) was performed as pre- 


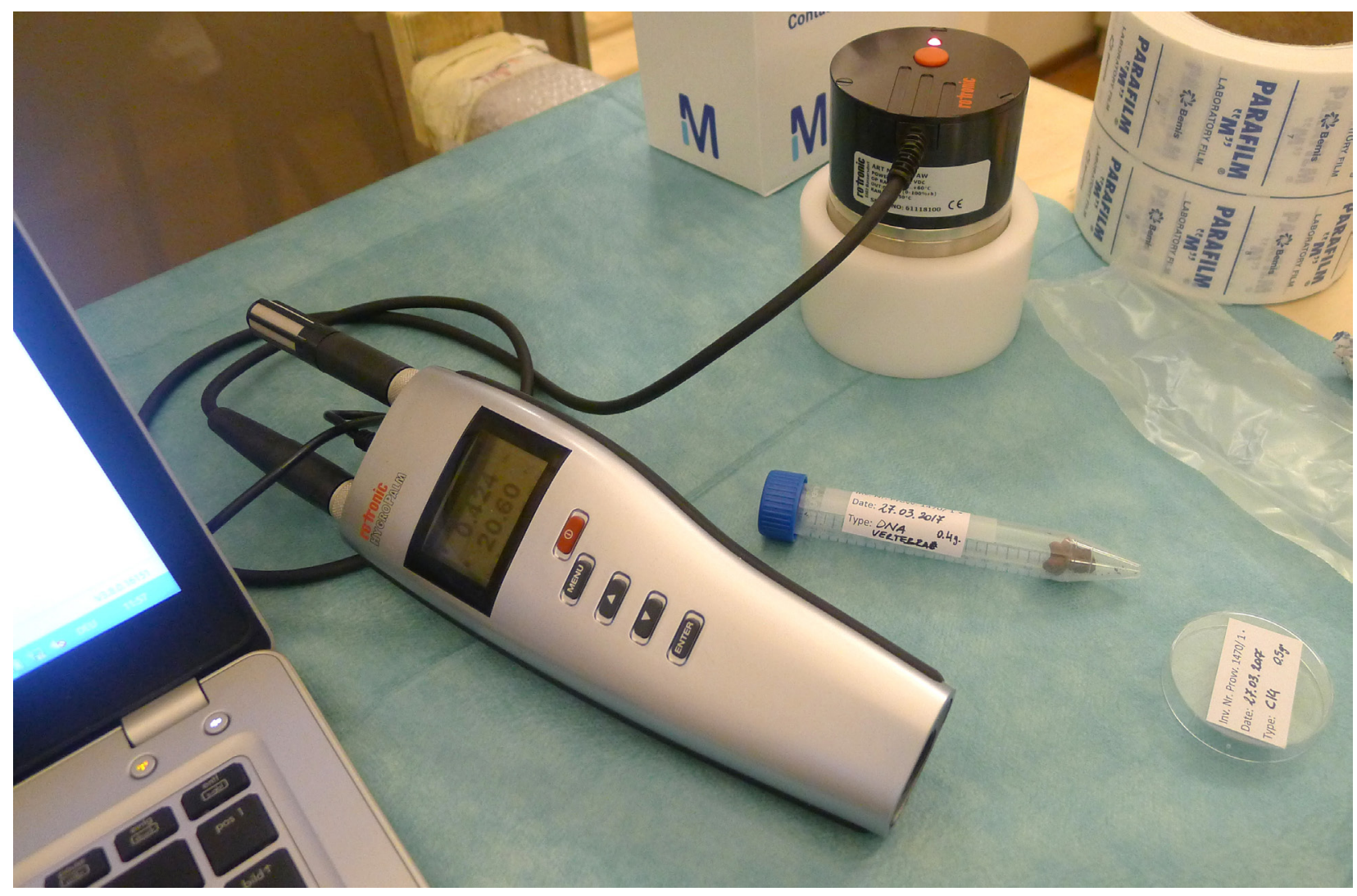

Fig. 2: Instrumental configuration for assessing water activity (aw). Picture by Marco Samadelli/Eurac Research, Institute for Mummy Studies.

viously described ${ }^{6}$ on different materials for the cultivation of superficial growing fungi (Fig. 3). The samples were taken from different materials found in the mummies, including soft tissue and textile material. We generated data from 18 mummies from the museum's storage room "Ipogeo magazzino visitabile" and 6 mummies stored in display cases. Air-borne fungi were collected on DG18 and $2 \%$ MEA plates using an air sampler (SAS) Super-90 (PBI International, Milan, Italy), with a sampling volume of 100 litres (Fig. 4). Fungi collected from the contact plates and air samples were purified by several transfers onto $2 \%$ MEA and DG18 plates.

\subsubsection{DNA extraction, PCR amplification and sequence analysis}

Pure cultures were identified based on the sequencing of internal transcribed spacer region (ITSI-5.8S-ITSII), a sequence that can be used as a phylogenetic marker. DNA was extracted from the purified cultures using fresh mycelia, as described by Michaelsen et al. ${ }^{7}$ For the analysis of fungal ITS sequences, we PCR amplified this genomic region using specific ITS primers, ${ }^{8}$ using the conditions described by Pinar et al. ${ }^{9}$ To identify the fungi, we compared the obtained sequence material to fungi ITS sequences available in the online public database NCBI, using the BLAST search program. ${ }^{10}$

\section{Results and discussion \\ 4.1 Observations on the results of water activity (aw) analysis}

Water activity analysis is a widely-used technique in food storage control. ${ }^{11}$ Its application in the field of cultural heritage conservation, on mummified biological samples, is innovative and pioneering.

The importance of relative humidity $(\mathrm{RH})$ to conservation is immense, ${ }^{12}$ and closely linked to the concept of water activity (aw), the parameter proportional to the escaping tendency of the water molecules present in the tissues constituting the mummy. Water activity (aw) is calculated as the ratio of the partial vapour pressure of water in tissues (Pw) to that of pure water $(\mathrm{Pw} 0)$ at the sample's surface temperature. ${ }^{13}$

After a certain time, any substance placed in a sealed 


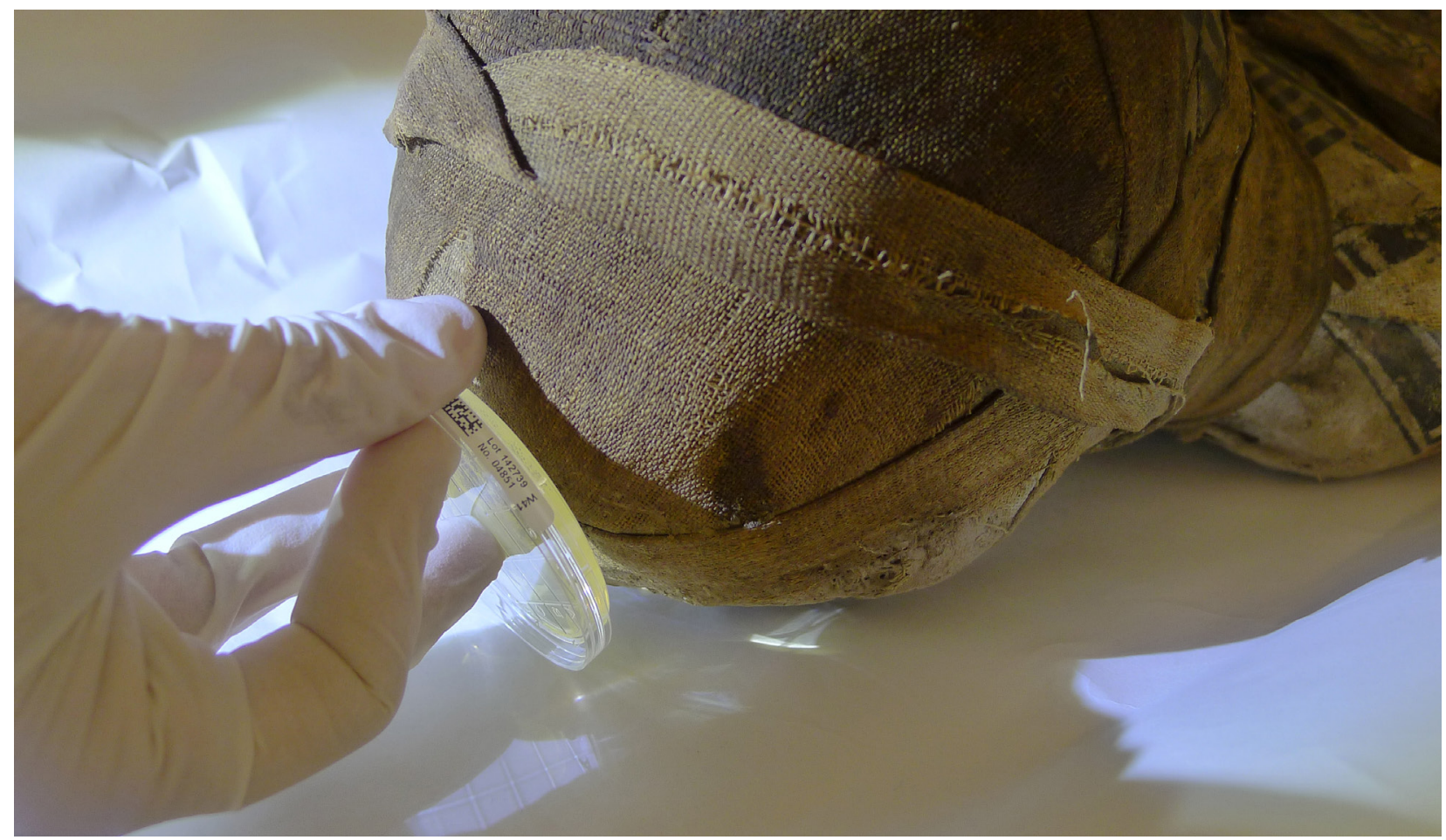

Fig. 3: Direct microbiological sampling on the surface of mummy Cat. 2245. Picture by Marco Samadelli/Eurac Research, Institute for Mummy Studies.

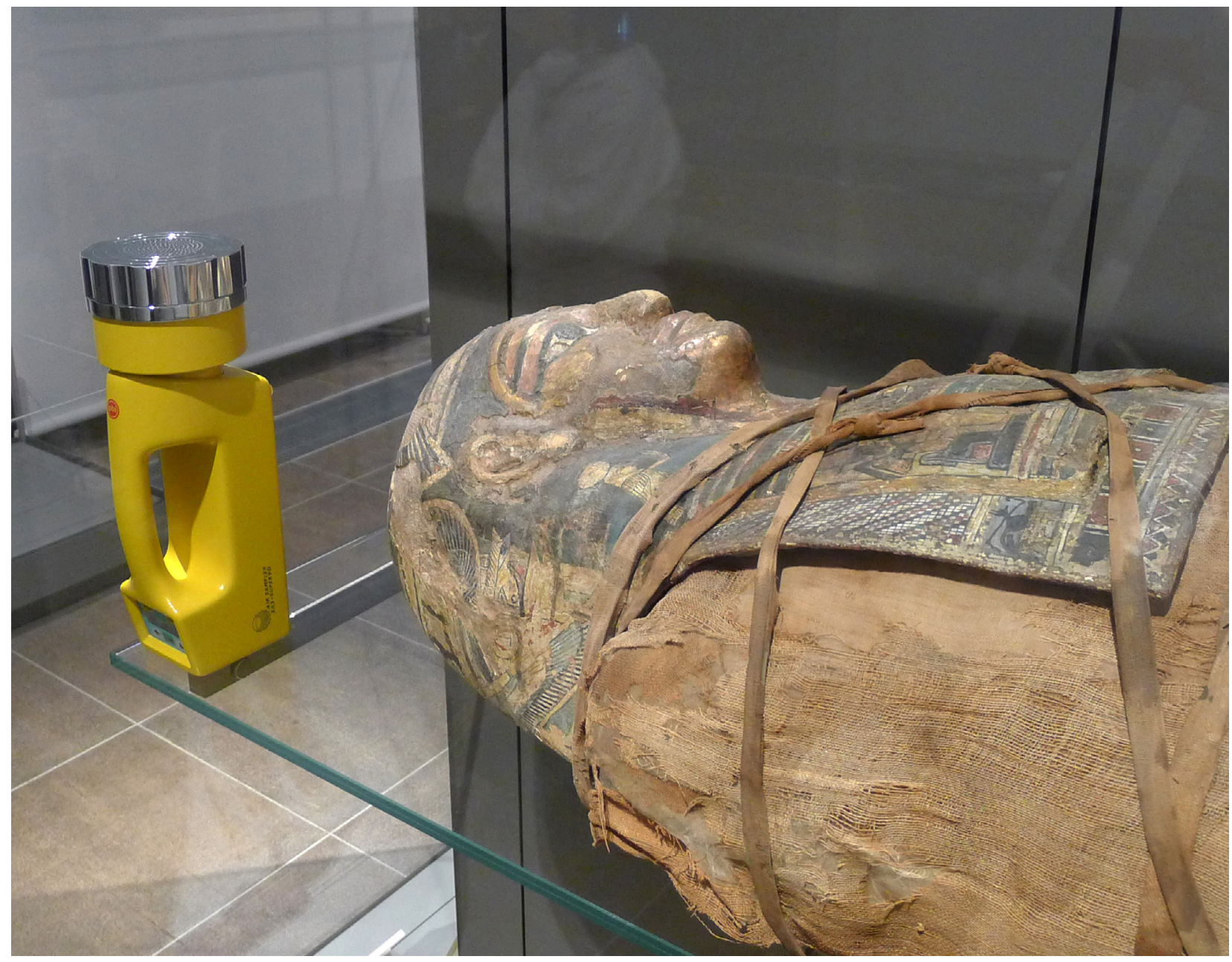

Fig. 4: Sampling of spores present in the air inside display cases (Suppl. 19691). Picture by Marco Samadelli/Eurac Research, Institute for Mummy Studies. 


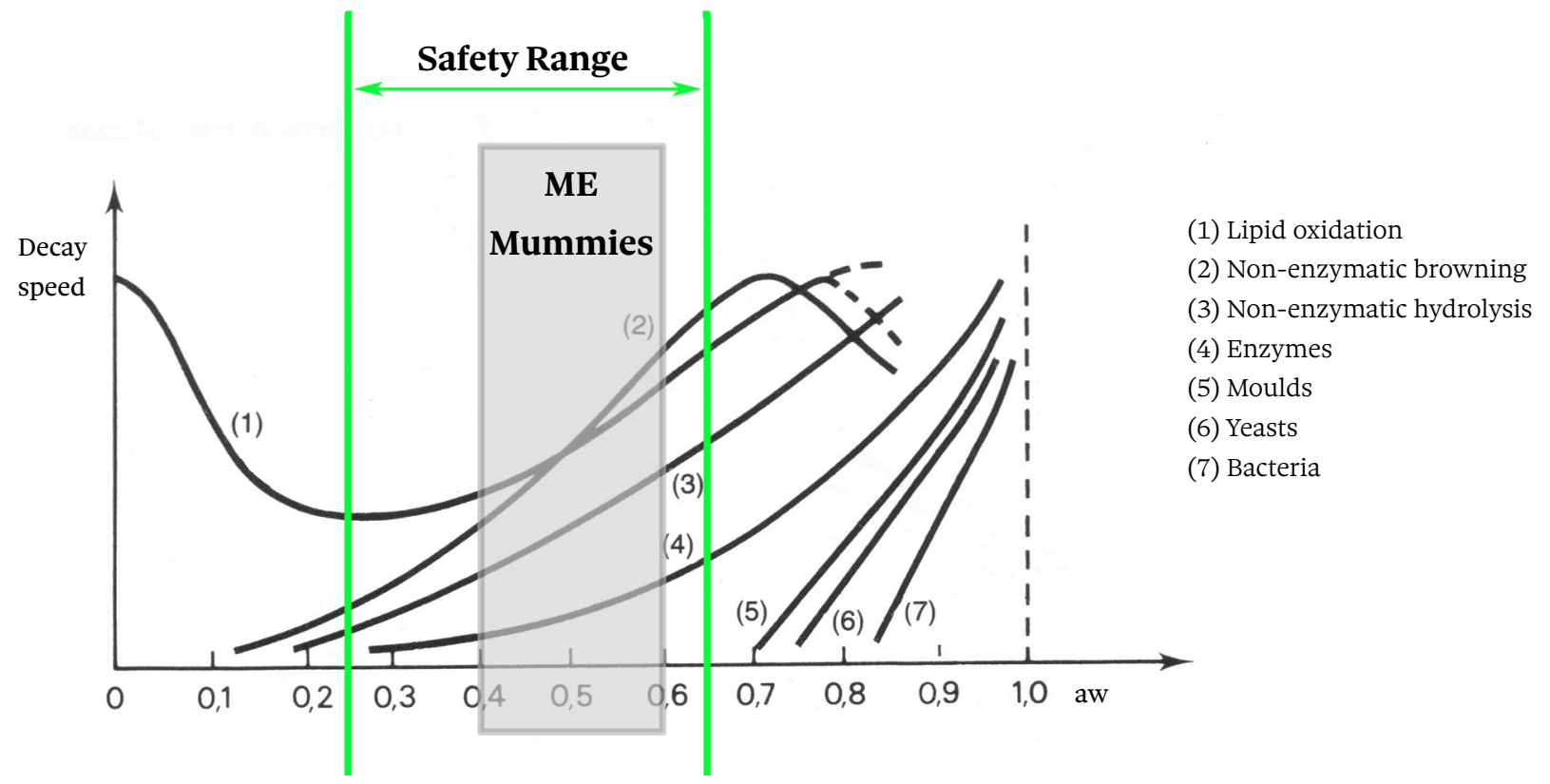

Fig. 5: Positioning of the results of water activity (aw) testing on the mummies in relation to the decay speed of organic tissues as a function of water activity (aw) [Labuza, T.P., 1975].

environment reaches a "thermal and hygrometric" equilibrium with the air surrounding it. Accordingly, the substance's moisture content reaches an equilibrium with the humidity of the environment (EMC). Under these conditions, the value of the air's equilibrium relative humidity (ERH) corresponds to the water activity (aw) value of the substance. ${ }^{14}$

From the chemical point of view, tissues constituting mummies can be considered as concentrated "solutions", and measurement and limitation of water activity (aw) are essential to the conservation process because they influence the life of microorganisms and enzyme activity. The greater the water activity (aw) value, the faster the decay of organic tissue, as synthetically represented in the chart (Fig. 5). ${ }^{15}$

Relative humidity values higher than $65 \%$, combined with temperature values higher than $20^{\circ} \mathrm{C}$, promote the development of moulds and accelerate the metabolism of many harmful insects. It is scientifically demonstrated that, with water activity (aw) lower than 0.3 , it is possible to inhibit the majority of the causes of biochemical decay in organic tissue. ${ }^{16}$ A total of 106 mummified samples were subjected to water activity (aw) tests. The results of the analysis are illustrated in Tables 1A and 1B (Tab. 1A and Tab. 1B).

The results of our water activity (aw) examination shows that most of the analysed mummies are in the range between 0.4 and 0.5 (aw) (Fig. 6). No differences were noted, with respect to this type of analysis, between one mummy and the other, even when kept in different environments. This uniformity of results is not surprising, because the same homogeneity was observed in the climatic parameters of the museum's exhibition environments and display cases, and of the mummy storage room.

In conclusion, observing the results of the water activity (aw) analysis on the mummified samples, reported in tables 1A and 1B (Tab. 1A and Tab. 1B), and comparing them with recent theoretical and experimental studies relative to the conservation of organic mummified finds, ${ }^{17}$ it can be stated that:

1. the observed water activity levels are consistent with those expectable in the environmental climatic conditions provided by the museum,

2. the analysed mummies are preserved within the safety parameters provided for proper conservation, as they all remain within the ideal range between $0.25-0.65$ (aw), as shown in Fig. $5 .^{18}$

\subsection{Microbiological analysis}

Through the fungal survey applied in this study, we were able to detect and identify different fungal genera and species on skin and textile samples taken from mummies from both the storage rooms and the display cases (Fig. 7). Interestingly, the number of 


\begin{tabular}{|c|c|c|c|c|c|c|}
\hline \multirow[t]{2}{*}{ Mummy (INV. N.) } & \multirow[t]{2}{*}{ Museum location } & \multirow[t]{2}{*}{ Sampling date } & \multicolumn{2}{|c|}{ Microbial survey } & \multirow[t]{2}{*}{$\mathbf{A W}$} & \multirow[t]{2}{*}{ Taw $\left({ }^{\circ} \mathrm{C}\right)$} \\
\hline & & & MEA2\% & DG18 & & \\
\hline Cat. 2211/2 & Ipogeo - magazzino visitabile - scaffale 04 - ripiano 3 & $28 / 03 / 2017$ & FS46 & FS45 & 0,4460 & 22,81 \\
\hline Cat. 2213/2 & Ipogeo - magazzino visitabile - cassa 009 & $31 / 03 / 2017$ & - & - & 0,4580 & 22,53 \\
\hline Cat. 2215/2 & Sala 11 vetrina 03 & $03 / 04 / 2017$ & - & - & 0,4391 & 23,18 \\
\hline Cat. 2218/2 & Sala 11 vetrina 03 & $03 / 04 / 2017$ & FS95 & FS96 & 0,4530 & 23,09 \\
\hline Cat. 2220/3 & Ipogeo - magazzino visitabile - scaffale 09 - ripiano 1 & $31 / 03 / 2017$ & FS80 & FS79 & 0,4476 & 22,40 \\
\hline Cat. 2223 & Ex-Antichità - cassa & $05 / 04 / 2017$ & - & - & 0,4170 & 24,65 \\
\hline Cat. 2230/1 & Sala 13 vetrina 01 & $05 / 04 / 2017$ & - & - & 0,4920 & 24,58 \\
\hline Cat. 2231/02 & Sala 11 vetrina 03 & $03 / 04 / 2017$ & - & - & 0,4530 & 22,77 \\
\hline Cat. 2233 & Ex-Antichità - cassa & $05 / 04 / 2017$ & - & - & 0,4239 & 24,31 \\
\hline Cat. 2245 & Ipogeo - magazzino visitabile - scaffale 04 - ripiano 1 & $29 / 03 / 2017$ & - & - & 0,4290 & 21,70 \\
\hline Cat. 2253 & Ipogeo - magazzino visitabile - scaffale 06 - ripiano 1 & $28 / 03 / 2017$ & FS35 & FS36 & 0,4221 & 22,32 \\
\hline Cat. 2254 & Ipogeo - magazzino visitabile - scaffale 06 - ripiano 3 & $28 / 03 / 2017$ & - & - & 0,4339 & 22,44 \\
\hline Cat. 2256 & Ipogeo - magazzino visitabile - scaffale 06 - ripiano 1 & $28 / 03 / 2017$ & FS39 & FS40 & 0,4021 & 22,49 \\
\hline Provv. 0549 & Ipogeo - magazzino visitabile - scaffale 04 - ripiano 2 & $28 / 03 / 2017$ & FS44 & FS43 & 0,4540 & 22,75 \\
\hline Provv. 0578 & Ipogeo - magazzino visitabile - scaffale 04 - ripiano 4 & $29 / 03 / 2017$ & - & - & 0,4200 & 21,48 \\
\hline Provv. 0610 & Ipogeo - magazzino visitabile - cassa + scaffale 14 - ripiano 1 & $31 / 03 / 2017$ & - & - & 0,4460 & 22,10 \\
\hline Provv. 0611 & Ipogeo - magazzino visitabile - scaffale 07 - ripiano 2 & $29 / 03 / 2017$ & FS57 & FS58 & 0,4891 & 25,15 \\
\hline Provv. 0612 & Ipogeo - magazzino visitabile - scaffale 07 - ripiano 1 & $30 / 03 / 2017$ & FS70 & FS69 & 0,4605 & 22,33 \\
\hline Provv. 0731 & Ipogeo - magazzino visitabile - scaffale 09 - ripiano 2 & $30 / 03 / 2017$ & - & - & 0,4310 & 22,62 \\
\hline Provv. 0996 & Sala 12 vetrina 06 & $27 / 03 / 2017$ & FS21 & FS22 & 0,4060 & 22,07 \\
\hline Provv. 1448 & Ipogeo - magazzino visitabile - scaffale 08 - ripiano 4 & $30 / 03 / 2017$ & - & - & 0,4231 & 20,81 \\
\hline Provv. 1449 & Ipogeo - magazzino visitabile - scaffale 08 - ripiano 2 & $29 / 03 / 2017$ & FS53 & FS54 & 0,4620 & 22,75 \\
\hline Provv. 1453 & Ipogeo - magazzino visitabile - scaffale 08 - ripiano 1 & $29 / 03 / 2017$ & - & - & 0,5005 & 22,87 \\
\hline Provv. 1456 & Ipogeo - magazzino visitabile - scaffale 04 - ripiano 3 & $28 / 03 / 2017$ & FS48 & FS47 & 0,4102 & 22,77 \\
\hline Provv. 1457 & Ipogeo - magazzino visitabile - scaffale 04 - ripiano 4 & $29 / 03 / 2017$ & - & - & 0,4411 & 20,40 \\
\hline Provv. 1468 & Ipogeo - magazzino visitabile - scaffale 06 - ripiano 1 & $29 / 03 / 2017$ & FS55 & FS56 & 0,5512 & 24,42 \\
\hline Provv. 1470/ 1 & Ipogeo - magazzino visitabile - scaffale 05 - ripiano 4 & $27 / 03 / 2017$ & - & - & 0,4150 & 20,65 \\
\hline Provv. 1471 & Ipogeo - magazzino visitabile - scaffale 07 - ripiano 3 & $29 / 03 / 2017$ & - & - & 0,4722 & 25,56 \\
\hline Provv. 1473 & Ipogeo - magazzino visitabile - cassa 007 & $30 / 03 / 2017$ & FS68 & FS67 & 0,4485 & 21,82 \\
\hline Provv. 1475 & Ipogeo - magazzino visitabile - scaffale 06 - ripiano 3 & $28 / 03 / 2017$ & FS25 & FS26 & 0,4489 & 20,63 \\
\hline Provv. 1478 & Ipogeo - magazzino visitabile - scaffale 09 - ripiano 2 & $30 / 03 / 2017$ & FS74 & FS73 & 0,4591 & 22,75 \\
\hline Provv. 1480 & Sala papiroteca - scaffale 12 & $03 / 04 / 2017$ & - & - & 0,4611 & 21,06 \\
\hline Provv. 1488/1 & Ipogeo - magazzino visitabile - scaffale 11 - scatola 06 & $05 / 04 / 2017$ & - & - & 0,6185 & 22,44 \\
\hline Provv. 1513/1 & Ipogeo - magazzino visitabile - scaffale 06 - ripiano 2 & $28 / 03 / 2017$ & - & - & 0,4310 & 20,03 \\
\hline Provv. 4156/2 & Magazzino legni, scatola 021 & $04 / 04 / 2017$ & - & - & 0,4520 & 22,83 \\
\hline Provv. 4243/1 & Magazzino legni, scatola 080 & $01 / 04 / 2017$ & - & - & 0,4762 & 22,35 \\
\hline Provv. 4765/2 & Ipogeo - magazzino visitabile - scaffale 08 - ripiano 4 & $06 / 04 / 2017$ & - & - & 0,5170 & 22,55 \\
\hline Provv. 5532 & Ipogeo - magazzino visitabile - scaffale 10 & $03 / 04 / 2017$ & - & - & 0,4611 & 20,62 \\
\hline Provv. 5535 & Magazzino "legni “sabauda" scaffale Q 4 & $05 / 04 / 2017$ & - & - & 0,5216 & 23,28 \\
\hline Provv. 6107 & Ipogeo - magazzino visitabile - scaffale 14 - ripiano 2 & $04 / 04 / 2017$ & - & - & 0,4591 & 22,62 \\
\hline Provv. 6108 & Ipogeo - magazzino visitabile - cassa 763 & $05 / 04 / 2017$ & - & - & 0,5152 & 23,14 \\
\hline Provv. 6112 & Ipogeo - magazzino visitabile - cassa 759 & $05 / 04 / 2017$ & - & - & 0,5280 & 22,94 \\
\hline Provv. 6126/7 & Ipogeo - magazzino visitabile - scaffale 4 - ripiano 3 & $06 / 04 / 2017$ & - & - & 0,5561 & 22,92 \\
\hline \begin{tabular}{|l|} 
Provv. 8135 \\
\end{tabular} & Ipogeo - magazzino visitabile - scaffale 09 - ripiano 4 & $30 / 03 / 2017$ & - & - & 0,4408 & 22,64 \\
\hline Suppl. 00278 & Sala 15 vetrina 02 & $27 / 03 / 2017$ & - & - & 0,4403 & 21,83 \\
\hline Suppl. 00293 & Sala 02 vetrina 01 & $06 / 04 / 2017$ & FS103 & FS104 & 0,4997 & 21,93 \\
\hline Suppl. 00304 & Ipogeo - magazzino visitabile - scaffale 08 - ripiano 3 & $29 / 03 / 2017$ & - & - & 0,5662 & 23,88 \\
\hline \begin{tabular}{|l|} 
Suppl. 05050 \\
\end{tabular} & Sala 10 vetrina & $27 / 03 / 2017$ & FS15 & FS16 & 0,4431 & 21,92 \\
\hline \begin{tabular}{|l|} 
Suppl. 05066 \\
\end{tabular} & Sala 10 vetrina & $27 / 03 / 2017$ & FS12 & FS11 & 0,4540 & 21,77 \\
\hline Suppl. 05109 & Magazzino "biblioteca", armadio A, ripiano 9 & $03 / 04 / 2017$ & - & - & 0,4490 & 22,56 \\
\hline Suppl. 05142/2 & Magazzino "biblioteca", armadio A, ripiano 9 & $03 / 04 / 2017$ & - & - & 0,4231 & 22,21 \\
\hline Suppl. 05147 & Magazzino "biblioteca", armadio A, ripiano 9 & $03 / 04 / 2017$ & - & - & 0,4110 & 21,76 \\
\hline Suppl. 05154 & Magazzino restauro & $01 / 04 / 2017$ & - & - & 0,5029 & 22,54 \\
\hline Suppl. 05226/2 & Sala 08 vetrina 09 & $27 / 03 / 2017$ & - & - & 0,3791 & 21,70 \\
\hline Suppl. 05227/2 & Sala 08 vetrina 08 & $27 / 03 / 2017$ & FS14 & FS13 & 0,4231 & 21,74 \\
\hline \begin{tabular}{|l|} 
Suppl. 05270 \\
\end{tabular} & Ipogeo - magazzino visitabile - scaffale 04 - ripiano 2 & $28 / 03 / 2017$ & FS41 & FS42 & 0,4131 & 22,58 \\
\hline \begin{tabular}{|l|} 
Suppl. 05271 \\
\end{tabular} & Ipogeo - magazzino visitabile - scaffale 01 - ripiano 3 & $31 / 03 / 2017$ & - & - & 0,4681 & 23,09 \\
\hline Suppl. 07715/01 & Sala 08 & $05 / 04 / 2017$ & - & - & 0,4745 & 22,91 \\
\hline \begin{tabular}{|l|l|} 
Suppl. 07716 \\
\end{tabular} & Sala 06 vetrina 07 & $05 / 04 / 2017$ & - & - & 0,4906 & 23,56 \\
\hline Suppl. 07717 & Soppalco - armadio 03 fibre vegetali - ripiano 3 & $04 / 04 / 2017$ & - & - & 0,4673 & 22,77 \\
\hline \begin{tabular}{|l|l|} 
Suppl. 07718 \\
\end{tabular} & Magazzino legni, scatola 120 & $04 / 04 / 2017$ & - & - & 0,4721 & 22,89 \\
\hline Suppl. 07719 & Magazzino legni, scatola 117 & $03 / 04 / 2017$ & - & - & 0,4511 & 22,87 \\
\hline
\end{tabular}

Tab. 1A: The results of the water activity (aw) value for the mummies, correlated with the acquisition temperature value Taw $\left({ }^{\circ} \mathrm{C}\right)$ of the room where the research operations were carried out. 


\begin{tabular}{|c|c|c|c|c|c|c|}
\hline \multirow[t]{2}{*}{ Mummy (INV. N.) } & \multirow[t]{2}{*}{ Museum location } & \multirow{2}{*}{ Sampling date } & \multicolumn{2}{|c|}{ Microbial survey } & \multirow{2}{*}{$\mathbf{A W}$} & \multirow{2}{*}{ Taw $\left({ }^{\circ} \mathrm{C}\right)$} \\
\hline & & & MEA2\% & DG18 & & \\
\hline Suppl. 08876/a & Ipogeo - magazzino visitabile - scaffale 03 - ripiano 1 & $31 / 03 / 2017$ & - & - & 0,4460 & 22,63 \\
\hline Suppl. 08942 & Ipogeo - magazzino visitabile - scaffale 13 - ripiano 4 & $31 / 03 / 2017$ & - & - & 0,4425 & 22,55 \\
\hline \begin{tabular}{|l|} 
Suppl. 08943 \\
\end{tabular} & Ipogeo - magazzino visitabile - scaffale 05 - ripiano 4 & $27 / 03 / 2017$ & - & - & 0,4328 & 20,89 \\
\hline Suppl. 08983/1 & Magazzino legni, scatola 025 & $04 / 04 / 2017$ & - & - & 0,4320 & 22,55 \\
\hline Suppl. 10534/3 & Ipogeo - magazzino visitabile - scaffale 05 - ripiano 3 & $27 / 03 / 2017$ & - & - & 0,4100 & 21,37 \\
\hline Suppl. 11110 & Ipogeo - magazzino visitabile - scaffale 04 - ripiano 4 & $28 / 03 / 2017$ & - & - & 0,4550 & 22,70 \\
\hline Suppl. $13086(?)$ & Ipogeo - magazzino visitabile - cassa 759 & $05 / 04 / 2017$ & - & - & 0,5410 & 22,46 \\
\hline Suppl. 13088 & Sala 03 vetrina 05 IN & $05 / 04 / 2017$ & - & - & 0,5080 & 22,87 \\
\hline Suppl. 13966/1 & Sala 03 vetrina $02 \mathrm{TdI}$ & $03 / 04 / 2017$ & - & - & 0,4231 & 22,93 \\
\hline Suppl. 14061/2 & Sala 02 vetrina 13 & $06 / 04 / 2017$ & - & - & 0,4980 & 22,93 \\
\hline Suppl. 14064/2 (?) & Ipogeo - magazzino visitabile - cassa 008 & $01 / 04 / 2017$ & - & - & 0,4690 & 21,71 \\
\hline Suppl. 14067, ex Suppl. 15815 & Sala 02 vetrina 08 & $04 / 04 / 2017$ & - & - & 0,4583 & 22,05 \\
\hline Suppl. 14168/01 & Magazzino vasi giallo, stanza 02 , armadio 8, TOP & $04 / 04 / 2017$ & - & - & 0,4561 & 22,75 \\
\hline Suppl. 14378/a & Sala 04 vetrina 07 (dentro sarcofago 14378) & $03 / 04 / 2017$ & - & - & 0,3951 & 23,21 \\
\hline Suppl. 14381/1 & Ipogeo - magazzino visitabile - scaffale 03 - ripiano 3 & $30 / 03 / 2017$ & - & - & 0,4490 & 22,87 \\
\hline Suppl. 14385/1 & Ipogeo - magazzino visitabile - scaffale 03 - ripiano 3 & $31 / 03 / 2017$ & - & - & 0,4330 & 21,16 \\
\hline Suppl. 14391/2 & Ipogeo - magazzino visitabile - scaffale 03 - ripiano 3 & $30 / 03 / 2017$ & - & - & 0,4450 & 22,66 \\
\hline Suppl. 14393/2 & Ipogeo - magazzino visitabile - scaffale 06 - ripiano 3 & $28 / 03 / 2017$ & FS32 & FS31 & 0,4310 & 22,05 \\
\hline Suppl. 14396/a & Sala 02 vetrina 16 & $03 / 04 / 2017$ & - & - & 0,4591 & 22,86 \\
\hline Suppl. 14415/2 & Ipogeo - magazzino visitabile - scaffale 08 - ripiano 2 & $29 / 03 / 2017$ & - & - & 0,4404 & 22,36 \\
\hline Suppl. 14426/2 & Ipogeo - magazzino visitabile - scaffale 03 - ripiano 4 & $30 / 03 / 2017$ & - & - & 0,4580 & 22,84 \\
\hline Suppl. $14435(?)$ & Ipogeo - magazzino visitabile - cassa 005 & $31 / 03 / 2017$ & - & - & 0,4391 & 22,95 \\
\hline Suppl. 14508 & Ipogeo - magazzino visitabile - scaffale 06 - ripiano 1 & $28 / 03 / 2017$ & FS30 & FS29 & 0,4552 & 21,49 \\
\hline Suppl. 14533/1 (?) & Ipogeo - magazzino visitabile - scaffale 06 - ripiano 4 & $28 / 03 / 2017$ & - & - & 0,4340 & 22,31 \\
\hline Suppl. 14650 & Ipogeo - magazzino visitabile - scaffale 10 & $01 / 04 / 2017$ & - & - & 0,4864 & 22,46 \\
\hline Suppl. 15741/1 & Ipogeo - magazzino visitabile - scaffale 07 - ripiano 4 & $31 / 03 / 2017$ & - & - & 0,4729 & 22,59 \\
\hline Suppl. $158[\ldots]=$ Suppl. 11173 & Magazzino vasi rosso, stanza 02, scaffale 06 & $05 / 04 / 2017$ & - & & 0,5093 & 24,90 \\
\hline Suppl. 15809 & Magazzino vasi giallo, Stanza 02 , armadio 8 , TOP & $04 / 04 / 2017$ & - & - & 0,4760 & 22,94 \\
\hline Suppl. 16090/2 (?) & Ipogeo - magazzino visitabile - scaffale 14 -ripiano 2 & $06 / 04 / 2017$ & - & - & 0,5260 & 22,58 \\
\hline Suppl. 16742 & Ipogeo - magazzino visitabile - scaffale 03 - ripiano 1 & $31 / 03 / 2017$ & - & - & 0,4439 & 22,69 \\
\hline Suppl. $16743(?)$ & Ipogeo - magazzino visitabile - scaffale 06 - ripiano 2 & $28 / 03 / 2017$ & FS27 & FS28 & 0,4710 & 21,04 \\
\hline Suppl. $16744(?)$ & Ipogeo - magazzino visitabile - scaffale 05 - ripiano 2 & $27 / 03 / 2017$ & FS06 & FS05 & 0,4498 & 21,24 \\
\hline Suppl. 16747/1 & Ipogeo - magazzino visitabile - scaffale 05 - ripiano 2 & $30 / 03 / 2017$ & - & - & 0,4751 & 22,49 \\
\hline Suppl. $16760(?)$ & Ipogeo - magazzino visitabile - scaffale 08 - ripiano 4 & $04 / 04 / 2017$ & - & - & 0,4300 & 21,22 \\
\hline Suppl. 16770/2 & Sala 02 vetrina 08 o ML sc 10 & $05 / 04 / 2017$ & - & - & 0,4989 & 22,96 \\
\hline Suppl. 16771 & Magazzino legni, scatola 011 & $01 / 04 / 2017$ & - & - & 0,4080 & 22,14 \\
\hline Suppl. 16772/2 & Magazzino legni, scatola 012 & $01 / 04 / 2017$ & - & - & 0,4832 & 22,28 \\
\hline Suppl. 16773/2 & Magazzino legni, scatola 013 & $03 / 04 / 2017$ & - & - & 0,4484 & 22,98 \\
\hline \begin{tabular}{|l|} 
Suppl. 16774 \\
\end{tabular} & Magazzino legni, scatola 014 & $04 / 04 / 2017$ & - & - & 0,4730 & 22,25 \\
\hline Suppl. 17045 & Ipogeo - magazzino visitabile - scaffale 03 - ripiano 4 & $04 / 04 / 2017$ & - & - & 0,4561 & 22,62 \\
\hline Suppl. 19691/3 & Sala 12 vetrina 06 & $27 / 03 / 2017$ & - & - & 0,4000 & 21,94 \\
\hline Suppl.5288_Prov_575 & Ipogeo - magazzino visitabile - cassa 760 & $06 / 07 / 2017$ & - & - & 0,4870 & 22,17 \\
\hline Suppl. 8431 & Sala 07 vetrina 04 & $03 / 04 / 2017$ & - & - & 0,4458 & 24,68 \\
\hline Suppl. 8471 & Sala 07 vetrina 06 & $03 / 04 / 2017$ & - & - & 0,4439 & 24,26 \\
\hline
\end{tabular}

Tab. 1B: Results of the water activity (aw) value for the mummies, correlated with the acquisition temperature value Taw $\left({ }^{\circ} \mathrm{C}\right.$ ) of the room where the research operations were carried out.

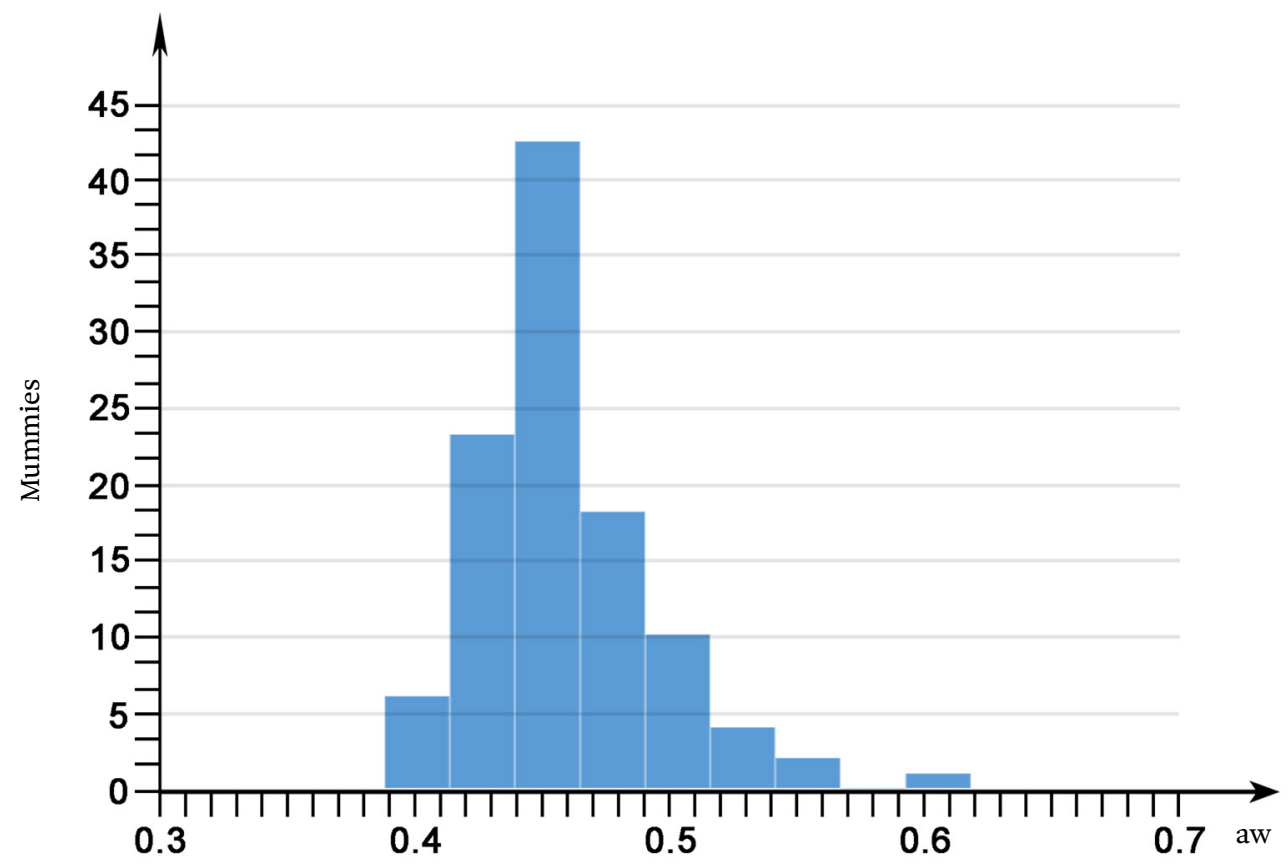

Fig. 6: Relationship between the number of mummies and the results of the water activity (aw) analysis. 


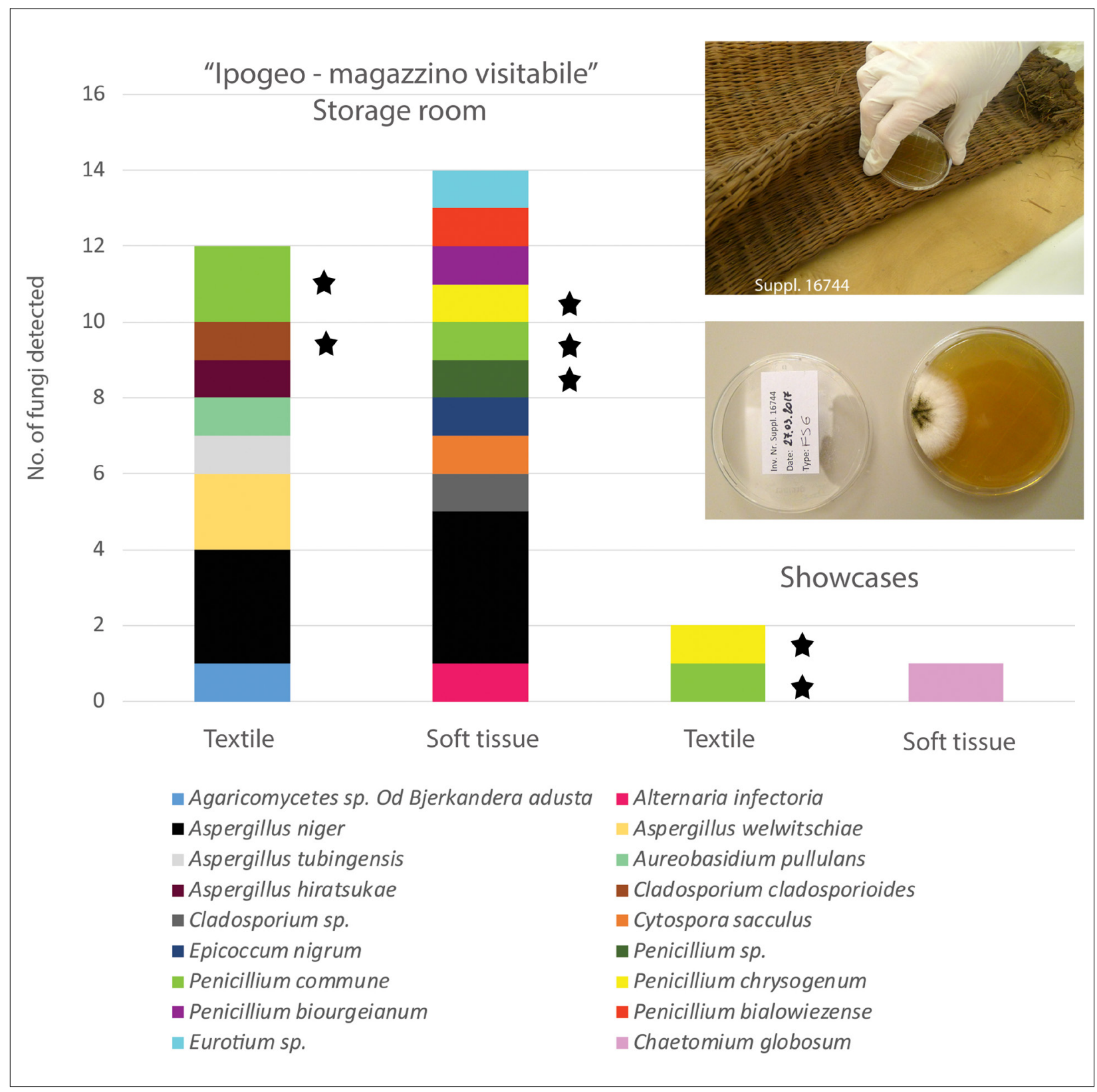

Fig. 7: Fungi detected on textiles and soft tissues of mummies from the storage room (Ipogeo, magazzino visitabile) and from display cases. The pictures on the upper right show a contact plate sampling on a grass mat and the fungal growth on the agar plate after incubation. The fungi marked with an asterisk have been detected both on the contact plates and in the air sampling.

different fungi detected on the storage room material $(n=17)$ is substantially higher than the ones from the display cases $(n=3)$. In addition, in contrast to the storage room samples, approximately half of the contact plates taken from the exhibition room samples display no fungal growth at all. This result indicates that the exhibition room material has a lower fungal spore and mycelia load in comparison to the material from the storage room. Further comparison of the detected contact plate fungi with the results obtained from air sampling indicates the presence of air-borne fungi in all the material analysed (Fig. 7, asterisks). For example, fungal species belonging to the genus Penicillium spp. were detected both on the material and in the air in the display cases. However, beside this acquisition and exchange of airborne fungal spores and mycelia, there still appear to be indigenous fungal communities present on different material. The fungal communities detected on the storage room textile or soft-tissue material on display clear sample-specific differences (Fig. 7). These differences become even more apparent when we take a closer look at the functional properties of the "material-specific" fungal species detected. Fungi 
such as Bjerkandera adusta, Aspergillus tubingensis, Cladosporium cladosporioides and Cytospora sacculus were only detected on the textile/plant material. ${ }^{19}$ For example, while sampling a grass mat using contact plates, we only observed the presence of one fungus, Aspergillus welwitschiae, which is known to be involved in the breakdown of fibrous plant material such as sisal ${ }^{20}$ (Fig. 7). Taken together, almost all the fungi detected in the textile material are commonly found saprophytes involved in degrading plant remains. In contrast, the soft tissue harboured unique fungal species such as Alternaria infectoria, a saprophytic fungus known to thrive on skin tissue. $^{21}$ In addition, we detected several Penicillium species (e.g. Penicillium chrysogenum) on the soft tissues, known for their proteolytic potential. ${ }^{22}$ There is therefore a clear indication of the presence of material-specific fungal communities.

\section{Final considerations}

In sum, our results indicate a still present biodegradational potential in the form of tissue-specific fungal communities (spores and mycelia), which could

\section{Notes}

${ }^{1}$ Scattolin Morecroft, in JEA 92 (2006), pp. 278, 281.

${ }^{2}$ Moiso, La storia del Museo Egizio (2016).

${ }^{3}$ For an overview on the mummies from Donati's and Drovetti's collection, see Fiore Marochetti in Boano and Rabino Massa (eds.), Mummie Egizie in Piemonte (2012), pp. 5-6; Boano et al., Mummie e mummificazione (2015); Delorenzi, Grilletto, Le mummie del Museo Egizio di Torino (1989).

${ }^{4}$ Boano et al., Le mummie del Museo Egizio di Torino (2008); Marro, Scavi Italiani in Egitto (1930).

${ }^{5}$ Boano et al. in Boano and Rabino Massa (eds.), Mummie Egizie in Piemonte (2012), p. 21.

${ }^{6}$ Piñar et al., FEMS Microbiology Ecology 86/2 (2013); Piñar et al., Extremophiles 18/4 (2014).

${ }^{7}$ Michaelsen et al., International Biodeterioration \& Biodegradation 58/3 (2006).

${ }^{8}$ White et al., in Innis et al. (eds.), PCR Protocols: A Guide to Methods and Applications (1990).

${ }^{9}$ Piñar et al., FEMS Microbiology Ecology 86/2 (2013).

${ }^{10}$ Altschul et al., Nucleic Acids Research 25/17 (1997).

${ }^{11}$ Cheftel et al. (eds.), Biochimica e tecnologia degli alimenti (1999).

${ }^{12}$ FprEN 16242.

${ }^{13} \mathrm{EN} 15803$.

${ }^{14} \mathrm{EN} 15803$.

${ }^{15}$ Labuza, in Cho-Kyun Rha (ed.), Theory, Determination and Control, 1975.

${ }^{16}$ Labuza, in Cho-Kyun Rha (ed.), Theory, Determination become a biodegradative risk as soon as the environmental conditions change, for example, at water activity levels above 0.65 (aw), which promote fungal growth. ${ }^{23}$ It is therefore of the utmost importance to keep the water activity levels of these unique cultural assets under constant control.

\section{Acknowledgements}

The authors wish to thank their partners for their valuable collaboration, without which it would not have been possible to complete this study project: the director of the Museo Egizio Christian Greco, Sara Aicardi, Susanne Töpfer, Valentina Turina, Biagio Sparacino (Museo Egizio, Turin), Giovanna Cipollini and Paola Bassetti (Eurac, Institute for Mummy Studies), Jagat Narula, Jim \& Linda Sutherland, Chris \& Heather Rowan, Samuel Wann, Klaus Fritsch, David Michalik, Sean Reardon, Emily Venable, Magdi Yacoub, Adel Allam, Michael Miyamoto (Horus Group), Toshiba Medical Systems Europe BV Netherlands, Gianni Monfardini (Artería S.r.l. Milan), Tiziana Mozzato, Silvia Vieceli (Starhotels Majestic, Turin).

and Control, 1975; Shin, Oxygen-Free Museum Cases, 1998; Samadelli et al., Journal of Cultural Heritage 14/6 (2013).

${ }^{17}$ Samadelli et al., Journal of Cultural Heritage 14/6 (2013).

${ }^{18}$ Labuza, in Cho-Kyun Rha (ed.), Theory, Determination and Control, 1975.

${ }^{19}$ Bensch et al., Studies in Mycology 67 (2010); Fan et al., Fungal Biology 119/5 (2015); Perrone et al., Applied Environmental Microbiology 72/1 (2006); Wang et al., Canadian Journal of Microbiology 49/11 (2003).

${ }^{20}$ Duarte et al., Frontiers in Microbiology 9 (2018).

${ }^{21}$ Dubois et al., Mycopathologia 160 (2005).

${ }^{22}$ Martín et al., Meat Science 62 (2002).

${ }^{23}$ Labuza, in Cho-Kyun Rha (ed.), Theory, Determination and Control (1975).

\section{Bibliography}

Altschul, S.F., T.L. Madden, A.A. Schaffer, J. Zhang, Z. Zhang, W. Miller, and D.J. Lipman, “Gapped BLAST and PSI-BLAST: A New Generation of Protein Database Search Programs", Nucleic Acids Research 25/17 (1997), pp. 3389-402.

Bensch, K., J.Z. Groenewald, J. Dijksterhuis, M. Starink-Willemse, B. Andersen, B.A. Summerell, H.D. Shin, F.M. Dugan, H.J. Schroers, U. Braun, and P.W. Crous, "Species and Ecological Diversity Within the Cladosporium Cladosporioides Complex (Davidiellaceae, Capnodiales)", Studies in Mycology 67 (2010), 
pp. 1-94.

Boano, R., R. Grilletto, A.M. Donadoni Roveri, E. Rabino Massa, and E. Fulcheri, "Le mummie del Museo Egizio di Torino: indagini diagnostiche preliminari sullo stato di conservazione", in F. Barbagli (ed.), Preparazione, conservazione e restauro dei reperti naturalistici: metodologie ed esperienze. Atti dei Seminari ANMS di Pavia, Museologia Scientifica Memorie 3 (2008), pp. 107-11.

Boano, R., G. Mangiapane, M. Girotti, and E. Rabino Massa, "La collezione antropologica egizia del Museo di Antropologia ed Etnografia dell'Università di Torino", in R. Boano and E. Rabino Massa (eds.), Mummie Egizie in Piemonte. Storia ed attualità in ambito egittologico ed antropologico, Torino 2012, pp. 21-22.

Boano, R., F. Cesarani, G. Gandini, R. Grilletto, E. Fiore Marocchetti, and M. C. Martina, "Mummie e mummificazione”, in Museo Egizio, Modena 2015, pp. 244-51.

Cheftel, J.-C., H. Cheftel, P. Besançon, and L. Didero (eds.), Biochimica e tecnologia degli alimenti, Bologna 1999², pp. 480-84.

Delorenzi, E., R. Grilletto, Le mummie del Museo Egizio di Torino. N. 13001-13026. Indagine antropo-radiologica (Catalogo generale del Museo Egizio di Torino, serie seconda - collezioni 6), Milano 1989, pp. 17-46.

Duarte, E.A.A., C.L. Damasceno, T.A.S. De Oliveira, L.D.O. Barbosa, F.M. Martins, J.R. De Queiroz Silva, T.E.F. De Lima, R.M. Da Silva, R.B. Kato, D.E. Bortolini, V. Azevedo, A. Gòes-Neto, and A.C.F. Soares, "Putting the Mess in Order: Aspergillus Welwitschiae (and not A. Niger) is the Etiological Agent of Sisal Bole Rot Disease in Brazil", Frontiers in Microbiology 9 (2018).

Dubois, D., M. Pihet, C.L. Clech, A. Croue, H. Beguin, J.P. Bouchara, and D. Chabasse, "Cutaneous Phaeohyphomycosis due to Alternaria Infectoria”, Mycopathologia 160 (2005), pp. 117-23.

EN 15803, Conservation of Cultural Property - Test Methods - Determination of Water Vapour Permeability, European Committee for Standardization (CEN), 2009.

Fan, X., K.D. Hyde, M. Liu, Y. Liang, and C. Tian, “Cytospora Species Associated with Walnut Canker Disease in China, with Description of a New Species C. Gigalocus”, Fungal Biology 119/5 (2015), pp. 310-19.

Fiore Marochetti, E., "Le mummie delle collezioni Donati e Drovetti al Museo delle Antichità Egizie di Torino", in R. Boano and E. Rabino Massa (eds.), Mummie Egizie in Piemonte. Storia ed attualità in ambito egittologico ed antropologico, Torino 2012, pp. 5-6.

FprEN 16242, Conservation of Cultural Property - Procedures and Instruments for Measuring Humidity in the Air and Moisture Exchanges Between Air and Cultural Property (under approval), European Committee for Standardization (CEN), 2012.

Labuza, T.P., "Sorption Phenomena in Foods: Theoretical and Practical Aspects", in: Cho-Kyun Rha (ed.), Theory, Determination and Control of Physical Properties of Food Materials, Food Material Science, I (1975), pp. 197-219.

Marro, G., "Scavi Italiani in Egitto e loro scopo antropologico”, XV Congrès International d'Anthropologie \& d'Archéologie Préhistoríque, IV Session de l'Institut International d'Anthropologie, Portugal, 21-30 septembre 1930, Paris 1931, pp. 1-8.

Martín, A., M.A. Asensio, M.E. Bermúdez, M.G. Córdoba, E. Aranda, and J.J. Córdoba, "Proteolytic Activity of Penicillium Chrysogenum and Debaryomyces Hansenii During Controlled Ripening of Pork Loins", Meat Science 62 (2002), pp. 129-37.

Moiso, B., La storia del Museo Egizio, Torino and Modena 2016, pp. 40-55.

Michaelsen, A., F. Pinzari, K. Ripka, W. Lubitz, and G. Piñar, “Application of Molecular Techniques for Identification of Fungal Communities Colonising Paper Material”, International Biodeterioration \& Biodegradation 58/3 (2006), pp. 133-41.

Perrone, G., G. Mulè, A. Susca, P. Battilani, A. Pietri, and A. Logrieco, “Ochratoxin A Production and Amplified Fragment Length Polymorphism Analysis of Aspergillus Carbonarius, Aspergillus Tubingensis, and Aspergillus Niger Strains Isolated from Grapes in Italy", Applied Environmental Microbiology 72/1 (2006), pp. 680-85.

Piñar, G., D. Piombino-Mascali, F. Maixner, A. Zink, and K. Sterflinger, "Microbial Survey of the Mummies from the Capuchin Catacombs of Palermo, Italy: Biodeterioration Risk and Contamination of the Indoor Air", FEMS Microbiology Ecology 86/2 (2013), pp. 341-56.

Piñar, G., L. Krakova, D. Pangallo, D. Piombino-Mascali, F. Maixner, A. Zink, and K. Sterflinger, "Halophilic Bacteria Are Colonizing the Exhibition Areas of the Capuchin Catacombs in Palermo, Italy", Extremophiles 18/4 (2014), pp. 677-91.

Samadelli, M., G. Roselli, V.C. Fernicola, L. Moroder, and A.R. Zink, "Theoretical Aspects of Physical-Chemical Parameters for the Correct Conservation of Mummies on Display in Museums and Preserved in Storage Rooms", Journal of Cultural Heritage 14/6 (2013), pp. $480-84$.

Scattolin Morecroft, A., "The Vitaliano Donati Collection at the Turin Egyptian Museum”, JEA 92 (2006), pp. 278-82.

Shin, M., Oxygen-free Museum Cases (series II - Research in Conservation), Getty Conservation Institute, 1998.

Wang, Y., R. Vazquez-Duhalt, and M.A. Pickard, "Manganese-Lignin Peroxidase Hybrid from Bjerkandera Adusta Oxidizes Polycyclic Aromatic Hydrocarbons More Actively in the Absence of Manganese", Canadian Journal of Microbiology 49/11 (2003), pp. 675-82.

White, T., T. Bruns, S. Lee, and J. Taylor, "Amplification and Direct Sequencing of Fungal Ribosomal RNA Genes for Phylogenetics”, in: M.A. Innis, D.H. Gelfand, J.J. Shinsky, and T.J. White (eds.), PCR Protocols: A Guide to Methods and Applications, San Diego 1990, pp. 315-22. 